\title{
Food problem and its solution
}

\author{
Vlasov, V. \\ National Scientific Centre, Institute of Agrarian Economics National Academy of Agrarian Sciences, \\ Department of Strategic Planning, Modeling and International Relations, Kiev, Ukraine \\ zed@iae.kiev.ua
}

SUMMARY

The Globalization processes substantially changed relations between countries. One of main factors of these processes is forming in XX century of Worldwide auction organization, which activity provided with swift growth of volumes in trade of food commodities. Thus, the solution for global food problem was found.

At the end of the second half of XX century the production volumes of agrarian goods in countries with a different level of economic development grew considerably. However, a food crisis 2007-2008 led to the necessity to define factors, which would allow to grow production, converting an agrarian sector into sustainable growing industry, passing ahead the increase of quantity of population.

Keywords: food security, population, agricultural production, sustainable growing agriculture, biotechnology, human resources, technologies, education

\section{INTRODUCTION}

A modern world is almost infinitely covered by globalization processes, which practical realization led the global restructuring of all the economy, enormous changes of international division of labor, system of international trade and its rules, forming of numerous conceptions of its development.

Only land is endowed with relatively unlimited resources because of its ability to produce the necessary to humanity agricultural primary products. This is important from the point of view, that only earth can constantly give products for renewable energy production, unlike incineration of petroleum, coal, gas, which proven reserves, after calculating, will be enough for, respectively, 69, 200 and 100 years (Поляков, 2005).

Keeping in mind, that internationalization and globalization, which began in the period of the great geographical discoveries, free motion of commodities, capitals and human resources founded the modern understanding of that our planet with its boundary demarcation between two hundred large and small states is, from the economic point of view, a sole home, a sole economy, holistic world space, sole global system (Білорус et al., 2009). Presently is formed the global system of world trade under the auspices of WTO by the rule of which was formed ,play" over 150 world countries.

Thus, in our opinion, the large part in this system is assigned to international trade by the products of agriculture and processing industry, that it is represented in modernized chart FAO (Figure 1) (Білорус and Власов, 2006). It should be noted, that for 1970-2010 the world volumes of export of agrarian products were multiplied with 51.9 to more than 1 billon dollars of the USA, or in 20.6 times, that it is related to the increase of production of agrarian goods.

\section{AGRARIAN PRODUCTION}

Therefore, it is expediently to consider system changes as an overcoming basis for global problems of malnutrition, which generalized could be defined by comparison of population growth rates as a factor, which predetermines a problem, and increase of production volumes of basic food commodities. According to our calculations (the statistical data FAO), during the period from 1961 to 2004 population of planet was annually growing in average on 73.2 million of people, or on $2.38 \%$ per year. In the highly developed countries those numbers were 347.5 million and $0.8 \%$, in developing countries, 2873.7 million and $3.11 \%$. At the same time agricultural production was also growing. Thus, the world average growth of grain was $3.59 \%$, growth of food grains (rice and wheat) 4.12 , meat and vegetables $5.9 \%$ and $6.6 \%$. At the meanwhile there is a clear systematic reorientation to the increase of production volumes of pork and poultry meat. At a world level the production of pork grew from 24.7 to 100.9 to million tons, either more than in 4 times, and poultry meat grew accordingly from 9 to 78.5 million tons, or more than in 8.7 times, while average annual growth rates were 6.99 and $17.68 \%$.

The analysis of these indexes in countries with a different level of development showed, that the average annual growth rates of grain production in the developed countries were $2.31 \%$, meat -2.1 that the vegetables 1.69 against $5.45,2.52$ and $11.69 \%$ in developing countries. Herewith, in developing countries the production of pork and poultry is being characterized with the highest growth rates - in 14 and almost in 20 times, accordingly. It means that in these countries more even bigger system changes were occurred in correlation of producing different types of meat in the interest of those industries, which are shortly able to grow production volumes while reducing its price. For example, the average cost of beef in the world market in 2000-2003 years was 2085 USD/t against accordingly in 20091179 USD/t for pork and meat of bird.

According to FAO prognosis, in 2050 The Earth will be inhabited with almost 9 milliard of people, and their basic part (up to 7.5 milliard) will be located in countries, that are presently related to poor. 
Figure 1: Trade policy, trade and food security

THE TRADE POLICY*

\begin{tabular}{|c|c|c|}
\hline $\begin{array}{c}\text { Export and imported policy } \\
\text { Tariffs, subsidies, standards } \\
\text { Rules of country of origin } \\
\text { Internal taxes }\end{array}$ & $\begin{array}{c}\text { Bilateral agreements } \\
\text { Regional unions, Multiregional unions } \\
\text { (for example ASEAN) }\end{array}$ \\
DETERMINANTS OF TRADE
\end{tabular}

\begin{tabular}{||l||}
\hline \multicolumn{1}{|c||}{ Internal } \\
- Macroeconomic policy, which is \\
determined by taxes, money policy, \\
exchange rate, target policy \\
- Access to earth, as to the main factor of \\
production \\
- Labor-market \\
- Technical providing of industry \\
- Development of production and processing \\
- Intechnologies \\
- Development of infrastructure \\
- Support of producers \\
- Competitiveness \\
- Investment policy \\
\hline \hline
\end{tabular}

\section{External}

- Change of tariffs

- Quoting

- Fluctuation in world prices

- Change of supply and demand level in world market

- Changing rules and standards between countries - exporters and countriesimporters

- Foreign investments partnership

- Food help

\section{FOOD SECURITY}

- Change of volumes of export and import

- Diversification of production

- Distributive system of products between the groups of population

with a different income level

- Growth of populations purchasing power

- Change of consumption and nutrition

- Change of budget items related to the food sphere

*A chart is modernized with the use of the positions expounded in Agricultural trade policy and food Security in the Caribbean. Rome (FAO, 2007).

Even along with current saving of existing, insufficient product consumption, it is needed to increase its production in not less than in one and a half times, and for global eradication of hunger the grain production in poorcountries must be doubled, and meat - to be threefold even. There are a few ways for solution of such a global task:

- Subsequent growth of agrarian areas. But, according to calculations, land reserves will be exhausted till the middle of a next century (Трегобчук, 1999).

- Reduction of losses during collection, transportation and harvest storage;

- Using of the intensive technologies of highly developed countries, with its further modification and adaptation to climatic conditions of concrete country in order to minimize usage of biological methods of plant protection, along with maintaining the efficiently level of intensive technologies. According to our calculations, intensification factors presently provide Asian countries with up to $20 \%$ growth rate of rice and $22-26 \%$ growth rate of corn.
- It is forced to use genetically modified organisms, despite the uncertain impact of them on human genome.

- Forming the global system of world trade, through which is possible to redistribute the surpluses of agricultural product into poor countries, which are presently forming in ,gold billion" countries and which for the last 30 years multiplied the export volumes of agricultural products and food in 9.5, and import - only in 7.5 times (Зубець et al., 2005).

At the same time, at the background of these positive changes a global food crisis happened (2007-2008), mainly caused by rapid products price increase and, as a result, products and food became inaccessible for a great part of population in poor countries, and also, according to experts evaluation, artificially created grain deficit on the World market, because of increase in biofuel processing. The situation worsened by the fact that almost in all 70 countries, that most felt a food crisis, own products are not enough and they are forced to increase its import almost constantly. 
The retrospective and current analysis allowed to define 10 basic factors, which will affect on growth of agricultural commodities and, accordingly, on trade development of agrarian products.

Forming in every country not just simply stable, but sustainable growing agriculture will be the first substantial factor. On such conditions the increase of production volumes will pass ahead population growth, that will provide gradual liquidation of shortage of food in those regions and countries of planet, where presently it (shortage) is especially tangible. It can be attained by development of technologies, improvement of management industry, strategy and tactics in policy in an agrarian sphere, while forming economically attractive, socially stable, highly productive agricultural systems, which do not harm to the natural environment, during gradual adaptation due to innovation and under act of changes in necessities in food. Forming of stable growing agriculture is more important, because up till now there is a global permanent shortage of food.

The structural changes of food stuffs production will be the second factor, predetermined by world tendencies in the division of labor and sizes of farms. Thus, China already ahead the USA by the grain production volumes, and by meat production exceeded them almost in 2 times, including produce of pork meat in 5 times. In African and Asian countries production of root crops and vegetables will proceed by faster paces in comparison with the developed countries.

The third factor are biotechnologies, which development is going extremely fast. It is followed by ambiguous processes. If recently some countries passed laws about import ban for genetically modified plants or its products to prevent possible negative influence on human genome, the other countries allow the product sales, where GMO were used, with obligatory pointing on the commodity label information that this product was produced using such plants, and a man must decide already, to consume it or not.

Nowadays we can boldly talk about the real transfer of biotechnological researches to a substantially higher level. It became obvious after French scientists report about the success in creation of genetically modified rice, where active matter rendering harmless wreckers is absent biologically. Especially important in here is that the matter appears in the plant only after the wreckers attack on it and only in that part of plant which was attacked. In the other words, there is the question about creating the second generation of genetically modified organisms, which production is harmless for a man. It is natural, that because of high cost of biotechnological researches poor countries are unable to carry them out. However, because of population growth and, as a result, increase in food demand along with limited financial resources, using such technologies as in high developed countries (integrated mechanization, herbicides, pesticides, fertilizers) will be forced to use genetically modified plants, which, while giving higher yield is requiring less labor and production costs.

It is also essential that genetically modified varieties can return back in use saline lands. In China, particularly, by participation of biotechnology were created new varieties of tomato, rice and soybean growing on such lands.
Fourth factor - it is the dynamics of changes in the necessities of human capital in agrarian production. It is characterized by abbreviation of its necessities in the developed countries as a result of introduction of intensive technologies at simultaneous growth of employees working in agriculture (in case of lack such a necessity) in poor countries, first of all in Asia and Africa. So, if in the developed countries in period from 1980 to 2010 the quantity of economically active population decreased from 70.9 to 26.6 million, or more than in 2.6 times, in developing countries this number grew from 890.4 to 1280.5 million, or more than in 1.4 times. For 1980-2010 years in African countries the quantity of this category of population grew from 118.1 to 214.6 million, or in 1.82 times, and in Asia - accordingly from 734.7 to 1023.2 , or in 1.39 times.

Herewith, if in the USA the quantity of economically active population in 2010 decreased comparing with 1980 in 1.56 times, in Canada in 2.43, in France in 3.46, in Germany in 3.7 times, in India it grew on 91.2 million, or in 1.51 times, and in China on 120.6 million, or in 1.32 times.

Technological gap in agricultural production systems, according to our calculations, led to, for example, that in EU every economically active agrarian produced in 2010 on the average 26.4 tons of corn, almost 4.2 tons of meat and 14.2 tons of milk against, accordingly, 801, 40 and $123 \mathrm{~kg}$ in the less developed countries. Such a gap has a tendency to growth. If in 1980 this index per one economically active agrarian was by grain production 8531 , by meat 1372 and by milk $6083 \mathrm{~kg}$, in 2010 the index already was over 25600,4100 and $14100 \mathrm{~kg}$.

As a result of such gap one economically active agrarian feeds in the USA 105, in Germany - over 90, in France -75 , and in India and China accordingly about 4 and 2.6 people. For this period in EU the efficiency of labor of every economically active agrarian grew in: by grain in 3, by a meat in 2.9 and by milk in 2.3 times, while in less developed countries - accordingly only in $1.3,1.4$ and 1.3 times.

Fifth factor - extraordinarily high necessity in development of agrarian research systems and its practical introduction. The work efficiency rise of network must become the strategic purpose for world association 16 research institutes of the CGIAR system - the Advisory group of international agricultural researches, which were specially created for the solution of food problem in poor countries. At the same time it is necessary to multiply research efforts of developed countries and volumes of their financing in order to create new and adapt existing intensive technologies in livestock and crops to climatic and socio-economic conditions of specific poor countries with consideration its educational level and mentality during implementation.

A sixth factor includes targeted changes in rural infrastructure. Farmers and other people living in rural areas of any country of the world, and especially in poor countries, need access to education, medical, informational and social service. Rural area also needs the improvement of transport networks and storage system of agricultural products. In many cases, building of roads or bridges through rivers can lead to considerable growth of agricultural production volumes in the specific region 
of a poor country as a result of acquired possibility for farmers to deliver the products to the market.

Seventh factor - this is development of world economic globalization process by accelerating the formation of global market, particularly market of agricultural raw materials and processing industry. Whereupon, change of positions of the developed countries about world agricultural development and development of agricultural market can be important, as offered by USA and EU reformation program of these two components of food security program was blocked on world negotiations in Cancun (Mexico, 2004) by developing countries, because the interests of poor countries were not taken into account. Ву Дж. Стігліц, commodities produced by farmers from poor countries can not compete with the products of Europe and the USA farmers, which have large state subsidies along with simultaneous use of import quotas against poor countries and other non-tariff barriers on the great number of commodities for defense of own market (Стігліц, 2003).

This how, tariffs on the imported agricultural commodities in rich countries are in average $27 \%$ against $17 \%$ in poor countries. EU, Canada, USA and Japan tax at maximum rates $60 \%$ of imported commodities from poor countries. Moreover, with the rise of processing level of products exported by poor countries, the custom tariffs escalation system starts working. In New Zealand, for example, a duty fee on a coffee beans is $5 \%$, and on ready to the use (ground coffee) is already $15 \%$.

The eighth factor (maybe the most important) is the introduction of reforms directed on more effective agricultural development. The first thing to be done is to grant the peasants a right of land ownership. According to the UN information, more than 500 million people, or approximately 100 million farms in poor countries are not the owners of the land they work on. Meanwhile, it is extremely important that women also should gain these rights, as they produce the major part of food stuff in those countries, which are located in Sub Sahara area.

The second thing is the further development of micro crediting system for poor farmers.

The third thing is the agricultural investments increase, the amount of which, for example in most African countries, makes less than $5 \%$ of all budgetary expenditures, though the welfare of $3 / 4$ part of the population directly or indirectly depends on agriculture.

The fourth thing to be done is the elimination of poor farmers' discrimination while granting a subsidy on input, first of all on the seeds of high-yield sorts.

The ninth factor - investing into the development of human capital through the increase of the educational level of the poorest part of the population. This allows improving the economics significantly by involving talents of different people into the economic which cannot be revealed because of the lack of education.

An evident example is the teaching programs on introduction the new ways of farm management. This provided a return rate of expenditure of $10-32 \%$ in Latin America and $91-100 \%$ in Kenya and Burkina Faso.

The tenth influential factor which should facilitate the growth of agricultural production is the population welfare increase in poor countries as a result of overall economic growth, which will ensure the growth of purchasing power.

According to UN, the annual GDP growth rate increase to $2.9 \%$ for $1990-2001$ against $2.3 \%$ for 1975-2001 per capita in the developing countries, caused the decrease of the World's share of people whose daily income is $1 \$$ and less from $28.5 \%$ in 1990 to $25 \%$ in 1999 , in the South Asian countries from $45 \%$ to $36.6 \%$ correspondingly, and in the East Asia and Pacific countries almost half as much - from $30.5 \%$ to $15.6 \%$. Thus the parity of purchasing power for 1993 2001 in poor countries grew almost on $40 \%$ against $36 \%$ on the average in a world (Власов and Лисак, 2011; Власов, 2006).

In addition, in the conditions of globalization of world economy, the availability of food for the population of planet, which is annually increasing on 70-80 million of people, in a great deal is determined by trade policy, by development of trade links on the agricultural markets, by production diversification, by the products distribution system for the population groups with different income, by the changes of tastes of people influenced by the global processes on the consumption of concrete products, by the change of purchasing power of population.

The population increase, the change of its age structure, people's physiological needs which were formed for thousands years and fastened genetically in every nation, and also economical aspects which are bounded to the level of general economical development and people's welfare, the possibility of purchasing as many products as needed for normal intellectual and physical development of a person - these are two main constituents of the food issue.

Our calculations shows that if the production level of grain, milk and meat per capita will stay the same as in 2009, when 2.5 billion tons of grain, 696 million tons of milk and 281 million tons of meat were produced, in 2020 , when the planet population will reach 7.7 billion people, it will be necessary to produce 2.9 billion tons of grain, 782 million tons of milk and 316 million tons of meat.

Only for production of corn at 2009 productivity level, about 800 million hectares of area will be needed against 700 million hectares in 2009. So, how do we get this 100 million hectares?

Generalization of the given and other data brought to the conclusion of the necessity of forming the integrated and open markets of agrarian commodities and technologies of their production.

They will be instrumental in creation of the global system of production planning and distribution of agrarian raw material and food within bounds of international division of labor. At the same time the change of the management rules of the world's economic order in the sphere of food production is needed, so that, as Джозеф Стігліц said, the current system of global management without a global government, which includes World Bank, IMF, WTO on world's level and the governments of countries and the world of commerce on the local level, will become aware of the humanity's necessities in food and satisfied them in a necessary volume. 


\section{CONCLUSION}

In general, World's agriculture plays the main role in economy, forming greater part of additional cost in processing industry and trade, providing more than the half of population of China, India and many countries of Africa with work.

According to the experts' predictions, by 2050 the population growth will cause the increase of food necessity by $70-90 \%$. At the same time as a result of growing shortage of water for agricultural production, the annual volume of world harvest can decrease by $30 \%$.

Therefore, in our opinion, both at the level of every country and at a world level an urgent development and introduction of the programs of forming "a sustainable growing agriculture", which will be based on intensive water saving technologies, at which the growth rates of production will pass ahead the growth rates of population. There is no other way out.

\section{REFERENCES}

Білорус, О. Г.-Зубець, М. В.-Саблук, П. Т.-Власов, В. І. (2009): Глобальна продовольча безпека. К. ННЦ „ІАЕ”. 9.

Білорус, О. Г.-Власов, В. І. (2006): Специфіка процесів глобалізації на сучасному етапі як чинники системних трансформацій і модернізації. Глобальна модернізація і сталий розвиток. Матер. міжвідомч. наук.-теорет. конф., м. Київ, 31 жовтня. 194.

Власов, В. І.-Лисак, М. (2011): Синопсис сільськогосподарських проблем у світі і складники продовольчої безпеки. Вісник національної академії наук України. 2: 37-48.

Власов, В.І. (2006): Тенденції та проблеми глобальних процесів у світовій продовольчій сфері. Економіка України. 3: 75-80.
Зубець, М. В.-Білорус, О. Г.-Власов В. І. (2005): Сільське господарство світу в умовах глобалізації. Вісник аграрної науки. 10: 5-9.

Поляков, В. (2005): Обеспеченность мировой экономики энергоносителями в XXI веке. МЭиМО. 6: 106- 112.

Стігліц, Дж. (2003): Глобалізація та їі тягар. Вид. дім „КМ Академія". 251.

Трегобчук, В. (1999): Продовольча безпека в контексті національної безпеки. Ін-т екон. НАН України. 56. 
